\title{
Response of the Uterus Commission of AGO to the Comment of M. Kolben, C. Dannecker and R. Kürzl
}

\author{
Kommentar der Kommission Uterus der AGO zur Stellungnahme von M. Kolben, C. Dannecker und R. Kürzl
}

Authors

Affiliations
G. Emons ${ }^{1}$, P. Mallmann ${ }^{2}$, acting for the Uterus Commission of AGO

${ }^{1}$ Universitäts-Frauenklinik, Gynäkologisches Krebszentrum, Göttingen

${ }^{2}$ Universitäts-Frauenklinik, Gynäkologisches Krebszentrum, Köln
Deutschsprachige Zusatzinformationen online abrufbar unter: www.thieme-connect.de/ ejournals/toc/gebfra
Bibliography

DOI http://dx.doi.org/

$10.1055 / \mathrm{s}-0034-1368261$

Geburtsh Frauenheilk 2014; 74 :

250 @ Georg Thieme Verlag KG Stuttgart · New York .

ISSN 0016-5751

\section{Correspondence}

Prof. Dr. med. Günter Emons,

Director of the University

Gynecological Hospital

Gynäkologisches Krebszentrum

Robert-Koch-Straße 40

37075 Göttingen

emons@med.uni-goettingen.de
We would like to thank our colleagues and the Munich Tumor Center for their comments. It is in the nature of things that statements such as those published in our update of the recommendations for the diagnosis and treatment of endometrial cancer are usually presented in an abridged form which cannot reflect all the nuances and the analysis. The basis for the carefully compiled statements will be explained in detail in the background texts of the upcoming S3 guideline for which funding has just been approved.

\section{Ad 1.) \\ $\nabla$}

As Kolben et al. correctly stated, endometrial cancer is found in at least $10 \%$ of cases with postmenopausal bleeding. Endometrial hyperplasia is diagnosed in a further $10 \%$, which - if it is atypical endometrial hyperplasia - constitutes a relevant precancerous lesion and is also an important indication of pathological estrogen production (steroid hormone-producing tumor). A cancer probability of $10 \%$ is sufficient to justify histological investigation. In breast examinations, histological investigations are already carried out if the cancer probability is $2 \%$. The Uterus Commission is familiar with the publications cited by Kolben et al. However, we consider the paper by Jacobs et al. (2011) [1] to be more relevant. Jacobs et al. reported that $20 \%$ of endometrial cancers were not detected in ultrasound investigations of endometrial thickness (cut-off < $5 \mathrm{~mm}$; $\mathrm{n}=30664$ ); however, 58 women required histological investigation to detect one case of endometrial cancer or atypical endometrial hyperplasia. The sensitivity and specificity of the method "bleeding in the post-menopausal period" is thus much higher. We therefore intend to stick with our recommendation. We agree with Kolben et al. that Pipelle biopsy is a suitable procedure for histological investigation. Pipelle biopsy is the standard method used in many countries and is usually carried out on an outpatient basis in doctors' practices without complications and without the need for anesthetics. This will be a very important issue for the S3 guideline, and it can be conjectured that the fractionated curettage method still very much favored in Germany will become less important.

\section{Ad 2.)}

The Uterus Commission wrestled for a long time as it attempted to find a better wording. "Atypical bleeding in perimenopausal women" is definitively too vague. We can definitely envisage using another wording, such as the one proposed by Kolben et al., and explaining it in greater detail in the accompanying background text compiled as part of the work on the $\mathrm{S} 3$ guideline. As we cannot provide such a differentiated approach in these short recommendations (What does "therapy resistant" mean?, What does "persistent" mean?), we would like to stick with the current wording. Here again, Pipelle biopsy carried out in doctors' offices is usually quite sufficient for sampling.

We would like to thank our colleagues Kolben, Dannecker and Kürzl for their considered comment and for the opportunity this provided to offer a more differentiated consideration of these issues.

\section{Conflict of Interest}

$\nabla$

There is no conflict of interest.

\section{References}

1 Jacobs I, Gentry-Maharaj A, Burnell M et al. Sensitivity of transvaginal ultrasound screening for endometrial cancer in postmenopausal women: a case control study with UK CTOCS cohort. Lancet Oncol 2011; 12: 38-48 